\title{
EKSISTENSI MISTISISME DALAM NOVEL AMBA KARYA LAKSMI PAMUNTJAK
}

\section{Arif Setiawan*, Musaffak}

Program Studi Pendidikan Bahasa Indonesia, Fakultas Keguruan dan Ilmu Penddidikan, Universitas Muhammadiyah Malang, Jl. Tlogomas 246 Malang, Indonesia

*Corresponding author: arifsetiawan@umm.ac.id

\section{INFORMASI ARTIKEL}

ABSTRAK

Sejarah Artikel

Diterima: $1 / 9 / 2019$

Direvisi: 25/11/2019

Diterima: $25 / 11 / 2019$

Tersedia Daring: 28/12/2019

Kata Kunci

Eksistensi,

Mistisisme,

Realitas Pengarang

Penelitian ini bertujuan untuk mendeskripsikan eksistensi mistisisme dalam novel Amba karya Laksmi Pamuntjak. Hal ini didasari oleh realitas bahwa pengarang termasuk ke dalam generasi yang tumbuh dan berkembang di lingkungan modern. Penelitian ini menggunakan metode deskriptif kualitatif. Data dalam penelitian ini berupa sekuen cerita dalam novel Amba karya Laksmi Pamuntjak yang menggambarkan eksistensi mistisisme. Sumber data dalam penelitian ini adalah novel Amba Karya Laksmi Pamuntjak. Setelah semua data terkumpul, maka data dianalisis berdasarkan fokus penelitian yang lebih menekankan pada eksistensi mistisisme tokoh utama pada tataran sarengat/syariat. Hasil penelitian menunjukan bahwa dalam novel Amba menampilkan eksistensi mistisisme tokoh utama pada tataran yang paling rendah yaitu syariat/sarengat. Eksistensi mistisisme tokoh utama dibuktikan dengan tetap percaya terhadap semua takdir yang digariskan oleh Tuhan, namun masih ada perilaku yang condong pada (1) arwah-arwah leluhur, (2) keberadaan dewa-dewa, dan (3) pahlawan mitilogi seperti seorang dukun.

\section{ABSTRACT}

Keywords

Existence

Mysticism

Author's Reality
The purpose of this study is to describe the existence of mysticism in the novel Amba by Laksmi Pamuntjak. It is based on the reality that the author belongs to the generation who grows in the modern environment. This study employed descriptive qualitative method. The data in this study were in the form of a story in the novel Amba by Laksmi Pamuntjak that illustrates the existence of mysticism. The data source in this study was the novel Amba from Laksmi Pamuntjak. After collecting them, the data were analyzed based on the focus of the research which emphasized the existence of the main character's mysticism at the Sarengat / Shariah. The results showed that Amba's novel presented the mysticism of the main character at the lowest level, namely Shari'a / Sarengat. The existence of the main character's mysticism was proven by continuing to believe in all the destiny outlined by God, yet there were some behaviors showing (1) ancestral spirits, (2) the existence of gods, and (3) mythological heroes like a shaman.

Copyright@2019, Arif Setiawan, Musaffak This is an open access article under the CC-BY-3.0 license
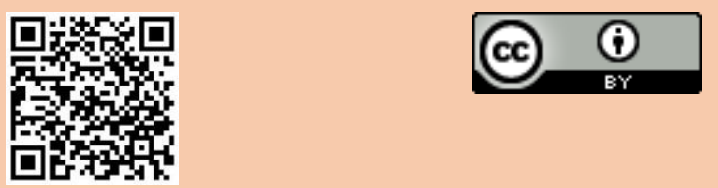

\section{PENDAHULUAN}

Karya sastra merupakan cerminan dari realitas kehidupan masyarakat yang terekam melalui deretan cerita yang ditulis oleh pengarang. Realitas kehidupan yang telah dituliskan pengarang mencakup semua aspek dalam kehidupan sehari-hari (Setiawan \& Qurani, 2017). Novel merupakan sebuah rangkaian cerita yang berisi semua aspek dalam kehidupan sehari- 
hari. Rangkaian cerita tersebut dibentuk berdasarkan karakteristik permasalahan dalam novel yang dibangun berdasarkan untuk intrinsik maupun ekstrinsik (Yusantia, Laila, \& Rahmat, 2019). Kedua unsur pembangun novel tersebut memiliki tujuan untuk menyampaikan pesan yang tersirat dalam teks sastra. Salah satu bentuk pesan yang disampaikan oleh pengarang kepada pembaca melalui teks sastra adalah eksistensi mistisisme (Nisa, 2019).

Mistisisme berasal dari kata mysterion yang memiliki makna rahasia, tersembunyi, gelap atau terselubung, dalam bahasa Indonesia dikenal dengan kata misteri atau misterius. Dengan demikian, dapat dikatakan bahwa mistisisme adalah pengetahuan yang sifatnya rahasia serta kaitannya antara manusia dengan Tuhannya yang melibatkan kalbu (Wahidi, 2013). Menurut Chalik (2015) mistik atau mistisisme memiliki kedekatan terhadap hal-hal yang misterius, mengaburkan, serta masih teka-teki. Dari uraian mengenai mistisisme yang telah dipaparkan dapat ditarik satu kesimpulan bahwa mistisisme berkaitan dengan keyakinan dan religiositas pribadi, oleh karenanya dapat dianggap sebagai urusan pribadi (Setiawan, 2019). Keyakinan dan religiositas yang bersifat pribadi tentunya memiliki pola dan kadar yang berbeda-beda pada setiap individunya (Furqon \& Busro, 2017). Mistisisme dalam pandangan Mulder dapat dilihat melalui motif, eksistensi, dan tujuan para pelaku misitisime itu sendiri (Mulder, 2013). Mistisisme dalam pandangan Mulder tersebut menjadi salah satu muatan yang mencolok dalam beberapa novel di era milenial yang masih mengemukakan motif, eksistensi, dan tujuan mistsisme. Salah satu novel yang masih menunjukkan eksistensi mistsisme di dalamnya adalah novel Amba karya Laksmi Pamuntjak.

Novel Amba karya Laksmi Pamuntjak mengusung latar sejarah kelam pada tahun 1965 di dalamnya. Pada tahun-tahun tersebut merupakan salah satu peristiwa yang cukup menarik banyak perhatian, karena terjadi banyak konflik di tanah air. Konflik yang terjadi berakar pada masa peralihan kekuasaan dari Orde Lama ke Orde Baru yang banyak terjadi di kalangan bawah atau simpatisan partai (Yuantisya, Nurizzati, \& Bakhtaruddin, 2018). Puncak konflik yang terjadi pada tahun tersebut adalah pecahnya adu ideologi antara PKI dan beberapa organisasi sayap kiri dengan aparatur negara. Kejadian tersebut cukup membawa dampak yang sangat buruk bagi beberapa pelaku sejarah, salah satunya Bhisma sebagai tokoh utama yang menjadi target atau daftar hitam pemerintah. Bhisma bersama dengan sejumlah orang yang terlibat dalam percik konflik di tahun 1965 tersebut, kemudian dibuang ke Pulau Buru di Ambon.

Dalam pengasingannya di Pulau Buru, Bhisma merupakan sosok lelaki yang telah memberikan pengalaman percintaan pada Amba meninggal dunia. Kondisi tersebut mendorong Amba untuk datang ke Pulau Buru dan membuktikan kebenaran informasi dengan cara menelusuri semua jejak tentang Bhisma. Selain itu, jalinan erat dalam novel Amba yang mengangkat epik terkenal dalam mitologi Jawa yaitu Mahabarata menjadi daya tarik tersendiri (Fitrahayunitisna, 2018). Kejadian berlatar sejarah dan epik mitologi Mahabarata yang digambarkan oleh Laksmi Pamuntjak menunjukkan jalinan cerita tentang eksistensi mistisisme dalam novel Amba. Selain itu, latar belakang pengarang yang termasuk ke dalam era modern juga mempengaruhi penggambaran eksistensi mistisisme. Hal ini dibuktikan dengan penggambaran eksistensi mistisisme dalam novel Amba melalui beberapa kejadian yang sangat dekat dengan kekuatan magis dan hal-hal yang berbau gaib seperti; percaya pada dukun, kuburan, penunggu hutan, serta melakukan praktik nyata dalam bentuk ritual atau upacara untuk mewujudkan keinginanya (Widijanto, 2018).

Eksistensi mistisisme yang terdapat dalam novel Amba karya Laksmi Pamuntjak dikaji berdasarkan tahapan mistisisme yang terbagi menjadi empat diantaranya; (1) tahap sarengat/syariat, (2) tahap tarekat, (3) tahap hakekat, (4) tahap makripat. Tahap sarengat/syariat merupakan tahapan yang paling dasar dalam eksistensi mistisisme, pada tahapan ini semua hal lebih dicondongkan kepada keberadaan dewa, roh, pahlawan atupun 
benda-benda mitologi yang berupa dukun, keris, dan tombak. Tahap tarekat merupakan tahapan dimana ibadah yang telah dilakukan bukan hanya sekedar menggerakan anggota tubuh dan melafalkan bacaan, melainkan sebagai upaya yang dilakukan untuk menjumpai Tuhan dalam keberadaan diri yang paling dalam. Tahap hakekat, merupakan perilaku yang mengedepankan individu jika melanggar larangan Tuhan, maka yang terjadi dalam kehidupan pribadi menjadi tidak sesuai dengan kaidah keagamaan, sehingga apa yang dilakukan mengalami kehmabaran atau kehilangan maknanya. Tahap makripat, merupakan tahapan yang paling tinggi karena tujuan setiap individu telah menyatu dengan Tuhan (Mulder, 2013).

Penelitian mengenai mistisisme juga pernah dilakukan sebelumnya oleh sejumlah peneliti. Penelitian relevan yang pertama dilakukan oleh Nisa (2019) yang berjudul Motif dan Eksistensi Mistisisme dalam Novel Misteri Perawan Kubur, Dendam Iblis Cantik, dan Dosa Turunan Karya Abdullah Harahap. Perbedaan dengaan penelitian relevan pertama dari segi objek kajian yang menggunakan novel dari pengarang yang berbeda. Selain itu, muatan dalam novel karya Abdullah Harahap dengan novel karya Lakmsi Pamuntjak yang digunakan sebagai objek juga sangat jauh berbeda. Penelitian ini juga memiliki sedikit persamaan dengan penelitian relevan yang pertama dari fokus eksistensi mistisisme menurut Neils Mulder. Akan tetapi, eksistensi dalam penelitian ini lebih mengarah pada bentuk pembuktian, karena novel yang digunakan sebagai objek merupakan novel yang lahir di tahun 2000-an. Penelitian relevan kedua dilakukan oleh Budiman (2016) dengan judul Representasi Mistisisme dan Seksualitas: Penerjemahan Budaya dalam Tiga Film Eksploitasi dari Indonesia. Penelitian relevan kedua menggunakan objek kajian berupa film yang menunjukkan ekpsloitasi (seksuaitas dan kekerasan) serta mistisisme yang menjadi ciri khusus film dari Indonesia. Penelitian relevan ketiga dengan judul Mistik dalam Novel Gentayangan Pilih Sendiri Petualangan Sepatu Merahmu Karya Intan Paramaditha (Tinjauan Sosiologi Sastra) yang dilakukan oleh Yusantia et al. (2019). Penelitian relevan ketiga menggunakan objek kajian novel Gentayangan Pilih Sendiri Petualangan Sepatu Merahmu, secara judul telah merepresentasikan mistisisme namun menggunakan teori yang berbeda. Di mana hasil penelitian tersebut menggambarkan (1) unsur mistik berupa kepercayaan terhadap hal gaib, (2) unsur mistik yang berupa sebab akibat yang tidak rasional, dan (3) unsur mistik berupa mitos. Perbedaan dengan ketiga penelitian sebelumnya adalah pada objek kajian yang berupa novel serta teori mistisisme Neils Mulder.

Novel Amba merupakan novel yang menyajikan kisah sejarah yang berlatar konlfik besar di tahun 1965, serta mengacu pada epik mitologi Jawa yaitu Mahabarata. Kedua perpaduan unsur tersebut menghasilkan sesuatu yang tepat dari sudut pandang mistisisme (Gunawan, 2016). Aspek tersebut yang menjadikan novel Amba menarik untuk dikaji dari perspektif eksistensi mistisisme di era modern. Hal ini sejalan dengan tujuan penelitian yang akan mengkaji eksistensi mistisisme dalam novel Amba berdasarkan teori dari Neils Mulder.

\section{METODE}

Sesuai dengan tujuan dan permasalahan yang dipaparkan, maka metode yang digunakan dalam penelitian adalah metode deskriptif kualitatif. Metode ini digunakan untuk mendeskripsikan dan menginterpretasi data-data yang tertulis dalam novel Amba karya Laksmi Pamuntjak. Penelitian ini menggunakan pendekatan sosiologi sastra, jenis penelitian ini adalah kualitatif. Sumber data dalam penelitian ini adalah novel Amba karya Laksmi Pamuntjak yang diterbitkan oleh Anggota IKAPI pada tahun 2013 dengan jumlah 577 halaman. Data dalam penelitian ini mencakup satuan cerita yang terwujud dalam dialog, monolog, paragraf, sekuen cerita, bagian kalimat, maupun narasi tokoh yang menunjukan eksistensi mistisisme. Teknik pengumpulan data yang dilakukan adalah menggunakan teknik studi dokumentasi. Teknik ini dilakukan berdasarkan tujuan penelitian, yakni memberikan gambaran mengenai eksistensi mistisisme. 
Pengumpulan data dilakukan dengan teknik studi dokumentasi atau studi kepustakaan dengan disertai pemahaman arti secara mendalam (sinverstehen) dan pemerian mendalam (thick description). Langkah-langkah yang dilakukan dalam proses analisis data sesuai dengan rancangan analisis data yang dipaparkan oleh Miles dan Huberman (Creswell, 2014). Model analisis data yang digunakan adalah flow model of analysis yang prosesnya dilakukan dengan langkah-langkah (1) penyeleksian data, (2) pemaparan data, dan (3) penarikan kesimpulan.

\section{HASIL DAN PEMBAHASAN}

Novel Amba yang diterbitkan pertama kali pada tahun 2013 oleh Laksmi Pamuntjak masih menyuguhkan eksistensi mistisisme di dalam rangkaian ceritanya. Hal ini menjadi sebuah bukti bahwa eksistensi mistisisme pada novel di era modern masih kental dan ada. Akan tetapi, bentuk eksistensi mistisisme tersebut masih pada tataran yang paling dasar yaitu syariat/sarengat berdasarkan kajian mistisisme Neils Mulder. Bentuk eksistensi mistisisme dalam novel Amba karya Laksmi Pamuntjak dipaparkan dalam uraian berikut.

\section{Perilaku yang Condong pada Arwah-Arwah Leluhur}

Eksistensi mistisisme dalam novel Amba digambarkan dengan baik oleh Laksmi Pamuntjak melalui tokoh Amba yang mencari keberadaan Bhsima. Pencarian yang dilakukan oleh Amba membawanya sampai pada satu tempat yang asing baginya, suasana yang terasa asing ternyata membawa konsekuensi tersendiri, seperti dalam kutipan berikut.

"Upacara di kuburan mungkin baru akan berakhir sejam lagi. Tapi aku yakin ini tempat aman buat kita saat ini" (PCAL ${ }^{1}, \mathrm{Amba}^{2}$ 2013:41)

Pencarian yang dilakukan Amba bersama Samuel, membawanya pada satu acara yang tengah dilakukan oleh masyarakat Buru. Acara yang diselenggarakan terlihat sedikit aneh, karena dilaksanakan di sebuah kuburan. Upacara tersebut bertujuan untuk memanggil dan berkomunikasi dengan arwah yang ada di dalam kuburan. Hiruk pikuk upacara yang dilakukan oleh masyarakat Buru di sebuah kuburan justru membuat Samuel sedikit bernafas lega, karena posisinya dengan Amba sekarang sedikit lebih aman. Akan tetapi, perasaan yang tengah dirasakan oleh Amba sedikit berbeda dengan Samuel. Amba yakin orang yang berada di dalam kubur tersebut adalah Bhisma yang selama ini dicarinya.

Satu hal tampaknya menyejukkan hatinya: orang-orang di desa ini sangat menghormati Bhisma, laki-laki di kuburan itu. Luar biasa bahwa setelah enam tahun kematiannya, mereka masih tetap mengadakan upacara khusus ( $\mathrm{PCAL}^{2}$, Amba, 2013:42).

Perasaan mendalam yang dirasakan Amba seolah telah menuntunnya untuk menemukan keberadaan Bhisma. Ternyata keberadaannya di tengah upacara yang dilakukan oleh masyarakat Buru menjadi sebuah jawaban atas apa yang selama ini dilakukannya bersama Samuel. Orang yang berada di dalam kuburan tersebut adalah Bhisma, sosok yang sangat dihormati oleh masyarakat Buru. Walaupun telah meninggal sejak enam tahun silam, namun nama dan kuburan Bhisma tetap menjadi satu tempat yang keramat. Masyarakat tetap mengadakan upacara khusus di kuburan Bhisma yang dimpimpin oleh Mauweng/imam. Upacara yang dilakukan tersebut bertujuan untuk menjaga komunikasi dengan Bhisma agar tetap menjadi pelindung bagi masyarakat desa. Upacara yang dilakukan oleh masyarakat desa, menjadi penyejuk bagi hati Amba yang tengah mencari satu kepastian terhadap orang yang sangat dicintainya. 
"Malam yang sama di soa Kepala Air di Waepo menyelenggarakan upacara bulan purnama untuk memperingati kematian sang Resi” ( $\mathrm{PCAL}^{3}$, Amba, 2013:43).

Selapas berada di upacara yang diadakan oleh masyarakat Buru, Amba dan Samuel juga mendapati suasana yang sama. Di satu desa bernama Waepo juga tengah menyelanggarakan upacara khusus untuk sang Resi yang tidak lain adalah Bhisma. Sedikit berbeda dengan tempat sebelumnya, upacara yang dilakukan oleh masyarakat Waepo adalah upacara bulan purnama. Upacara ini dianggap sebagai salah satu penghormatan dan peringatan kepada kematian Bhisma. Selain itu, upacara bulan purnama yang diadakan di kuburan sang Resi juga sebagai bentuk komunikasi dengan arwah dari sang Resi yang dipimpin oleh kepala suku atau Mauweng.

"Pak, Ki Amongraga dan istrinya dikisahkan bertemu dengan keluarga mereka setelah mereka meninggal. Bagaimana orang yang sudah mati berkomunikasi dengan orang yang masih hidup?"

"Kamu percaya ndak ada makhluk gaib?"

Amba terdiam.

"Kamu percaya ndak, Nduk?"

"Dalam hati Amba berkata, tentu saja aku percaya makhluk gaib. Setiap hari ada saja temanku di sekolah yang mengaku lihat setan. Bukan rampok atau maling, tapi setan. Salah satu paman si Sati suka mengatakan ia kenal semua hantu yang gentayangan di kuburan dekat sekolah" (PCAL ${ }^{4}$, Amba, 2013:108)

Dalam sebuah diskusi ringan dengan Bapak, Amba mencoba memaparkan informasi yang telah didapatinya tentang Ki Amongraga dan istrinya yang telah meninggal. Setelah meninggal arwah keduanya bertemu dengan keluarga besarnya untuk berkomunikasi. Tentu saja hal tersebut membuat Bapak sedikit tidak percaya dan berbalik bertanya pada Amba. Dengan suara khasnya, Bapak menanyakan pada Amba dengan pertanyaan sederhana. Kamu percaya ndak ada mahluk gaib? Pertanyaan tersebut sampai diulang dua kali oleh Bapak. Pertanyaan bapak tentu saja menunjukan satu hal yang bersifat mendasar, yaitu bertanya mengenai satu keyakinan pada Amba. Tanpa jawaban yang terucap, hati Amba menjawab dengan pasti bahwa dirinya percaya terhadap mahkluk gaib. Keyakinan Amba tersebut dibuktikan dengan beberapa kejadian yang dialaminya oleh sebagian teman-temanya di sekolah. Bahkan kejadian yang dialami oleh teman-temanya hampir setiap hari dan silih berganti. Satu hal lagi yang dipercayai oleh Amba adalah semua teman yang telah bercerita mengenai pengalamannya bertemu setan, bukan rampok ataupun maling. Hal ini juga diperkuat oleh penyataan teman Amba di sekolah, bahwa pamannya mengenal semua hantu yang bergentanyangan di kuburan dekat sekolah. Semua kondisi tersebut seolah mengukuhkan keyakinan Amba terhadap keberadaan mahkluk gaib atau arwah-arwah gentayangan yang berada di sekitarnya.

"Mbak pasti tahu, berabad-abad lamanya Kediri telah kena tulah," katanya dengan nada seorang yang berada di luar waktu. "Pada malam-malam tertentu ada orang yang mendengar kuku kaki kuda yang mengetuk jalan-jalan yang berbatu, desah prajurit-prajurit yang ketakutan mendengar Empu Gandring mengucapkan kutukannya saat Ken Arok menikam jantungnya. Mereka semua tahu, kekerasan akan datang dan raja akan saling membunuh. Dan kekerasan itu akan selalu berulang" (PCAL ${ }^{4}$, Amba, 2013:184). 
Perputaran waktu membawa Amba ke suatu tempat yang terkenal akan aura negatif yang selalu menyertainya, tempat tersebut adalah Kediri. Kediri merupkan bekas kerajaan yang pernah mengalami kejayaan di masa sejarah nusantara. Warna nusantara dan sejarah tersebut menjadi satu topik menarik yang dibisikkan pada Amba dalam diskusi ringan di sore hari. Dalam pembicaraan tersebut, orang asli Kediri memaparkan hal-hal yang tidak masuk diakal atau sukar dipercaya. Mulai dari sejarah panjang Kediri yang telah terkena tulah selama bertahun-tahun. Selian itu, pada malam-malam tertentu selalu didengar suara tapal kaki kuda di atas jalanan yang berbatu. Bukan hanya suara tapal kaki kiuda saja yang dapat didengar pada malam-malam tertentu. Melainkan ada juga suara desah para prajurit yang ketakutan dengan sumpah serapah yang diucapkan oleh Empu Gandring pada Ken Arok. Sumpah serapah tersbeut diucapkan oleh Empu Gandring pada Ken Arok yang telah menghunuskan keris tepat di jantungnya. Kejadian ini seolah berulang pada beberapa generasi setelah Ken Arok, sesuai dengan apa yang dikatakan oleh Empu Gandring pada Ken Arok saat menghunus jantung Empu Gandring dengan keris buatannya. Kejadian tersebut seolah menandakan bahwa masih ada sebagian orang yang percaya terhadap arwah-arwah yang telah meninggal, termasuk sumpah serapah yang diucapakannya.

"Tanpa kepulan asap, gendering, bunga-bunga, dan upacara. Atau mungkin yang tak terduga-duga adalah upacara itu sendiri. Setidaknya itulah yang terjadi: pertemuan Amba dan Bhisma pada suatu hari Kamis, pada hari pertama Amba di Kediri, di kota tempat raja-raja membunuh dan dibunuh" ( $\mathrm{PCAL}^{4}, \mathrm{Amba}$, 2013:186)

Pertemuan Amba dengan Bhisma sendiri seolah seperti suatu kejadian yang sukar dipercaya. Hal ini terjadi tanpa melalui sebuah kebiasaan yang melekat pada masyarakat dalam bentuk adat istiadat. Kebanyakan masyarakat Kediri selalu memiliki upacara atau ritual tersendiri untuk mempertemukan dua anak manusia. Apalagi Kediri dikenal sebagai salah satu kota yang penuh sejarah dengan raja-raja yang saling membunuh demi sebuah kejayaan. Tentu kondisi yang demikian menyiratkan setiap lakuan acara sakral seharusnya berdasarkan balutan ritual agar terhindar dari tulah. Akan tetapi, pada kondisi yang tengah dialami Amba dan Bhisma tidak ada ritual yang mengiringi pertemuannya.

\section{Perilaku yang Condong pada Keberadaaan Dewa-Dewa}

Eksistensi mistisisme kedua yang digambarkan oleh Laksmi Pamunjtak dalam novel Amba diwujudkan dalam bentuk perilaku yang condong pada keberadaan para dewa. Eksistensi tersebut dapat dilihat dari lakuan tokoh utama yang percaya terhadap keberadaan para dewadewa seperti halnya kutipan berikut ini.

"Bahkan Samuel turut kagum. Ia sendiri, yang sudah cukup lama menetap di Buru, dan kenal seluk-beluknya, belum pernah bertemu Manalisa, meskipun seperti siapa pun juga yang pernah tinggal di pulau ini lebih dari seminggu tahu bahwa Manalisa adalah penguasa Buru yang sejati. Ia mahatahu, maha di manamana. Ia resi, pendekar, setengah dewa, pembuat mukjizat. Konon tak ada satu jiwa pun yang tak dapat ia binasakan, atau yang tak dapat ia lindungi dari kematian. Orang Buru juga percaya, siapa pun yang tak layak ia kenal, atau yang tak menarik perhatiannya, tak akan bisa melihatnya" ( $\mathrm{PCKD}^{1}, \mathrm{Amba}$, 2013:58) 
Samuel yang telah lama tinggal di Buru dan telah mengenal setiap jengkalnya belum pernah sama sekali bertemu dengan Manalisa. Tersirat sebuah kekaguman dalam diri Samuel karena bertemu dengan Manalisa, sosok penguasa Buru yang sejati. Sosok Manalisa merupakan gambaran nyata dari perwujudan pendekar yang sakti mandraguna, dewa yang mahatahu, dan maha berada di setiap jengkal Pulau Buru. Konon kesaktian yang dimiliki oleh Mnalisa telah membuatnya dapat membinasakan siapa saja serta ia lindungi dari kematian. Kesaktian tersebut juga membuatnya tidak dapat dilihat oleh sembarang orang. Kesaktian tersebut membuat masyarakat Buru menjulukinya sebagai seorang dewa yang maha tahu dan maha di mana-mana.

"Setiap kali kelompok itu tak berhasil mendapatkan binatang buruan, sebelum malam turun Manalisa menemukan sisa batang pohon yang telah ditebang, lalu meminta semua anggota kelompok berpaling, dan menembak, dan tiba-tiba saja, sisa batang pohon menjelma babi hutan atau rusa" $\left(\mathrm{PCKD}^{2}, \mathrm{Amba}\right.$, 2013:58).

Sudah kesekian kalinya masyarakat Buru merasa terbantu dengan keberadaan Manalisa sebagai penguasa setiap jengkal Pulau Buru. Hal ini dibuktikan dengan kisah sekelompok masyarakat Buru yang tengah melakukan perburuan binatang di hutan. Setiap kali kelompok gagal mendapatkan binatang buruan, selalu saja kondisi ini diketahui oleh Manalisa. Dengan kesaktian yang dimiliki Manalisa, dia dapat mengetahui keberadaan kelompok pemburu yang masih belum mendapatkan binatang buruannya. Seketika itu juga, tangan dingin atau bentuk kesaktian yang dimiliki oleh Manalisa telah mengubah batang pohon yang ditebang menjadi hewan buruan seperti babi hutan dan rusa. Setiap kali melakukan hal tersebut, Manalisa selalu meminta kelompok pemburu untuk berbalik dan menembakkan senjatanya, seketika juga terhampar binatang buruan yang dicarainya.

"Ia tak punya dan tak butuh pengikut. Suaranya seperti salak serigala. Diceritakan bahwa jika ia marah, tanah di sekitarnya menggelegak dan mendidik dan menjelma kawah" (PCKD ${ }^{3}$, Amba, 2013:58)

Nama besar Manalisa memang tidak pernah pudar, di balik nama besar dan segala kesaktian yang dimilikinya, dia tidak pernah membutuhkan pengikut atau murid. Hal ini seolah membuktikan bahwa Manalisa lebih menyukai kesendirian yang membuatnya dapat bergerak bebas di Pulau Buru. Selain itu, keengganan memiliki pengikut ditunjang oleh kondisi fisik Manalisa, kondisinya digambarkan memiliki suara seperti salak serigala dan sangat menyeramkan. Ditambah dengan kondisi yang cukup menakutkan ketika Manalisa marah, semua tanah yang berada di sekitar pijakannya serta merta akan menjelma seperti kawah. Semua informasi mengenai kesaktian Manalisa seolah membenarkan sebutan dewa yang melakat pada dirinya.

"Juga dikisahkan ia satu-satunya orang di Buru yang tahu tempat persembunyian para jugun ianfu, perempuan-perempuan yang diciduk dari tempat tinggal mereka di Jawa untuk dijadikan budak seks tentara Jepang yang bertugas di Pulau Buru antara 1942 dan 1945, sebelum mereka ditinggalkan di pulau itu pada akhir Perang Dunia Kedua" (PCKD ${ }^{4}$, Amba, 2013:59)

Bentuk kesaktian lainnya yang dimiliki oleh Manalisa adalah kemampuannya untuk mengentahui tempat persembuyiaan para jugun ianfu. Jugun ianfu adalah sebutan untuk para 
perempuan yang diculik dari tempat tinggal mereka di Jawa dan menjadi budak seks tentara Jepang. Para perempuan tersebut harus menerima nasib malangnya sebagaai budak seks dan akhirnya harus tinggal di Pulau Buru, dan sampai akhirnya ditinggal oleh tentara Jepang setelah perang dunia kedua. Nasib jugun ianfu menjadi sebuah rahasia besar yang ada di Pulau Buru dan hampir tidak banyak orang yang mengetahuinya. Akan tetapi, bagi Manalisa hal ini dapat diketahuinya dengan mudah karena kesaktian yang dimilikinya. Kesaktian tersebut seolah hampir menyerupai dewa-dewa yang telah terlahi dengan membawa sesuatu yang berbeda. Hal ini seolah juga telah mendarh daging pada diri Manalisa yang memiliki kesaktian luar bisa layaknya dewa.

\section{Perilaku yang Condong pada Pahlawan Mitilogi seperti Seorang Dukun}

Eksistensi mistisisme selanjutnya yang terdapat dalam novel Amba diwujudkan dalam bentuk perilaku yang condong pada pahlawan mitologi seperti seorang dukun. Eksistensi mistisisme dapat dilihat dari paparan cerita yang terdapat dalam novel seperti kutipan berikut ini.

"Istilah lokal. Imam, kepala suku, dukun penyembuh, semua jadi satu. Semua desa di semua soa di Buru punya mauwengnya masing-masing. Nanti, sehabis upacara di kuburan, warga desa akan rame-rame balik ke rumah ini" (PCPMSD ${ }^{1}$, Amba, 2013:41)

Setipa daerah di Pulau Buru memiliki satu distrik yang dipimpin oleh seorang imam, kepala suku, dukun penyembuh atau Mauweng. Mauweng memiliki peran yang sangat vital karena setiap jengkal yang akan dilakukakn oleh masyarakat Buru selalu harus berdasarkan keputusannya. Sebagai seorang pemimpin atau dukun yang dapat menyembuhkan penyakit, maka Mauweng harus selalu hadir dalam setiap upacara yang dilaksanakan di kuburan. Hal ini dikarenakan setiap laku dari seoranng Mauweng merupakan perwakilan komunikasi dengan roh yang dipanggli dalam setiap upacara yang digelar. Apabila keinginan atau kehendak sudah dikomunikasikan oleh Mauweng kepada roh halus yang telah dipanggil, maka satu persatu masyarakat akan kembali ke rumahnya. Kejadian ini seolah terus berulang setiap kali ada sesuatu yang ingin dikomunikasikan kepada arwah para leluhur.

"Kami tidak lebih baik," sahut Amba. "Kami cenderung mengangap semuanya bisa diselesaikan oleh sihir dari dukun dan doa" (PCPMSD" ${ }^{1}$ Amba, 2013:173)

Satu kondisi yang tengah dihadapi oleh Amba membuatnya sedikit berbicara dengan cepat dan tidak terkondisikan. Satu kata yang kemudian terlontar dari mulut Amba adalah kondisinya yang tidak lebih baik. Kondisi tersebut didadasarkan atas apa yang tengah dilakukan oleh Amba dan menggantungkan pada sebuah sihir dari seorang dukun atau sebuah doa dan tanpa berusaha. Hal ini seolah menandakan bahwa Amba menggantungkan pada keberadaan dan kekuatan sihir dari seorang dukun untuk menyelesaikan masalah.

\section{Pembahasan}

Berdasarkan hasil analisis data pada bagian hasil, didapati bentuk eksistensi mistisisme dalam Novel Amba yang dituliskan oleh pengarang. Eksistensi mistisisme digambarkan oleh pengarang melalui lakuan tokoh dalam novel. Eksistensi mistisisme yang digunakan dalam menelaah novel Amba adalah berdasarkan mistisisme Jawa menurut Mulder. Mulder (2013) memaparkan mistisisme menjadi empat bagian yang terdiri dari; (1) Syariat/sarengat, tahap ini merupakan tahap yang paling rendah dalam tataran mistisisme, di mana pada lakuannya setiap 
individu akan melakukan perilaku mendasar seperti mencondongkan diri pada arwah-arwah, dewa, dan pahlawan mitilogi seperti dukun untuk mewujudkan segala sesuatu yang diinginkan. (2) Tarekat, pada tahap ini dapat dikatakan merupakan pengejawantahan ibadah sebagai salah satu bentuk persiapan untuk menemui Tuhan. (3) Tahap hakekat merupakan tahapan yang lebih mengedepankan perilaku pada setiap individunya. Apabila melanggar perintah Tuhan maka kehidupan peribadi tidak lagi sesuai dengan kaidah keagamaan, sehingga ibadah yang telah dilakukan kehilangan maknanya. (4) Tahap makrifat, pada tahapan ini merupakan tingkatan yang paling tinggi, karena setiap lakuan ibadah yang dilakukan oleh manusia telah menyatu dengan Tuhan. Jiwa pelaku/individu telah melebur menjadi satu kesatuan dan memiliki tujuan yang sepenuhnya murni. Dari keempat tahapan mistisisme yang dipaparkan oleh Mulder, eksistensi mistisisme yang terdapat dalam novel Amba hanya pada tataran yang pertama yaitu syariat/sarengat.

\section{Perilaku yang Condong pada Arwah-Arwah Leluhur}

Dalam novel Amba perilaku yang condong pada arwah-arwah leluhur digambarkan melalui beberapa lakuan tokoh yang melakukan upacara di kuburan. Upacara yang dilakukan di kuburan bertujuan untuk menjalin komunikasi dengan arwah-arwah yang telah meninggal. Selain itu, upacara yang dilakukan juga memiliki tujuan untuk menghormati setiap jasa yang telah diberikan mendiang sewaktu masih hidup. Perilaku lainya selain upacara diwujudkan dalam bentuk kepercayaan terhadap keberadaan arwah-arwah leluhur yang tertuang dalam sebuah cerita atau cerita rakyat. Cerita rakyat diutarakan dari mulut ke mulut dan dijadikan sebagai pedoman bagi beberapa orang yang mempercayainya. Hal inilah yang digambarkan dengan jelas oleh pengarang dalam novel Amba di mana tokoh utama sangat mempercayai beberapa ritual dalam bentuk upacara di kuburan dan keberadaan arwah-arwah para leluhur.

Berbeda dengan penelitian yang telah dilakukan oleh Nisa (2019), hasil penelitian ini lebih menggambarkan eksistensi mistisisme dalam bentuk upacara tanpa melalui tapa (semedi). Lakuan yang terdapat dalam penelitian sebelumnya digambarkan oleh pengarang melalui tapa (semedi) untuk mencapai keinginannya. Selain itu, dalam melakukan tapa (semedi) pelakunya harus melakukan dalam kondisi yang tenang, sendiri, dan dengan pembersihan jiwa, sehingga tujuan dapat tercapai. Melalui proses tapa (semedi) individu tersebut telah berhasil menundukkan hawa nafsunya untuk menggali potensi batinnya. Dengan demikian, eksistensi mistisisme dalam novel karya Abdullah Harahap diwujudkan melalui tapa (semedi) untuk berkomunikasi denga arwah-arwah. Perbedaan yang mendasar adalah penggambaran eksistensi mistisisme yang dilakukan dalam novel Amba tidak melalui tapa (semedi), melainkan melalui upacara yang digelar di atas kuburan. Upacara ini digelar dengan menggunakan beberapa alat musik dan jauh dari unsur kesendirian dan tenang. Hal ini sejalan menurut Miswari (2017) bahwa pengalaman dan kepercayaan itu dirasakan melalui kehadiran yang sangat meyakinkan, keyakinan tersebut melebihi eksistensi diri yang hadir seketika dan pergi juga dalam kondisi yang demikian.

\section{Perilaku yang Condong pada Keberadaaan Dewa-Dewa}

Perilaku yang condong terhadap dewa-dewa digambarkan oleh pengarang dalam novel Amba melalui keberadaan Manailsa. Sosok Manalisa merupakan penggabaran yang sangat sempurna layakanya dewa. Setiap lakuan Manalisa selalu berhubungan dengan sesuatu yang berada di luar nalar manusia. Hal ini dibuktikan dengan setiap detail kejadian yang terjadi di Pulau Buru diketahui oleh Manalisa, bahkan sampai pada tempat persembunyian para jugun ianfu atau perempuan budak seks tentara Jepang juga ia ketahui. Hasil penelitian ini berbeda dengan penelitian yang telah dilakukan sebelumnya oleh (Nisa, 2019). Penelitian sebelumnya tidak menguraiakan mengenai eksistensi mistisisme dalam bentuk perilaku yang condog pada 
dewa-dewa. Data yang menunjukkan perilaku yang condong pada dewa dapat dikatakan sebagai temuan dalam penelitian yang mengkaji eksistensi mistisisme menurut pandangan Mulder.

\section{Perilaku yang Condong pada Pahlawan Mitilogi seperti Seorang Dukun}

Perilaku yang lebih condong pada pahlawan mitilogi seperti seorang dukun digambarkan dalam novel Amba melalui peran Mauweng. Mauweng merupakan kepala suku, imam, atau dukun penyembuh yang dipercaya oleh masyarakat Pulu Buru untuk menyelesaikan semua yang diinginkan. Mauweng memegang peran penting dalam setiap ritual atau upacara yang diadakan oleh masyarakat Buru. Apapun yang akan dilakukan oleh masyarakat harus sepengetahuan Mauweng, sehingga semuanya dapat terkondisikan dengan baik. Hal ini seolah menyiratkan bahwa peran Mauweng sangatlah tinggi dalam setiap aktivitas masyarakat Buru, sehingga semua harus melalui sepengetahuan Mauweng.

Penelitian relevan menjelaskan bahwa eksistensi mistisisme diwujudkan perilaku yang condog pada dukun. Perilaku yang condong pada dukun juga digambarkan melalui lakuan tapa (semedi) (Miswari, 2017). Perbedaan penelitian yang relevan dengan penelitian ini adalah lakuan Mauweng dalam setiap acara atau ritual yang dilakukan oleh masyarakat Buru, tidak harus melalui tapa (semedi). Lakuan dari Mauweng diwujudkan dalam bentuk memimpin upacara di kuburan, serta mendoai air yang akan diminumkan ke orang sakit. Hal ini menujukkan eksistensi mistisisme yang diwujudkan dalam bentuk lebih modern dan tidak terikat pada tapa (semedi). Lakuan Mauweng sejalan dengan pendapat Rudin (2017) bahwa sifat dasar mistisisme merupakan gejala gaib seperti telepati, kemampuan membaca pikiran, atau menempatkan pada posisi yang lebih tinggi, sehingga mampu memberi jalan keluar bagi yang membutuhkannya.

\section{SIMPULAN}

Berdasarkan hasil analisis yang telah dilakukan dalam penelitian ini, dapat disimpulkan bahwa eksistensi mistisisme dalam novel Amba digambarkan pada tahap yang paling dasar yaitu syariat/sarengat. Pada tahap syariat/sarengat eksistensi mistisisme diwujudkan dalam bentuk perilaku yang condong pada arwah-arwah, dewa-dewa, dan pahlawan mitologi seperti dukun. (1) Perilaku yang condong kepada arwah-arwah ditemukan dalam bentuk upacara yang dilakukan di kuburan Bhisma sebagai sang Resi. Selain itu, ditemukan juga dalam bentuk kepercayaan terhadap cerita rakyat yang beredar di masyarakat mengenai keberadaan raja-raja di Kediri. (2) Perilaku yang cenderung terhadap dewa-dewa ditemukan dalam bentuk kepercayaan terhadap keberadaan Manalisa yang memiliki kekuatan layaknya seorang dewa. (3) Perilaku yang condong terhadap pahlawan mitologi seperti dukun, ditemukan data dalam bentuk kepercayaan masyarakat terhadap Mauweng atau dukun di kalangan masyarakat Buru.

\section{DAFTAR PUSTAKA}

Budiman, R. (2016). Representasi Mistisisme dan Seksualitas: Penerjemahan Budaya dalam Tiga Film Eksploitasi dari Indonesia. Makna (Jurnal Kajian Komunikasi, Bahasa, dan Budaya), 1(2), 49-61.

Chalik, A. (2015). Sintesis Mistik dalam Kepemimpinan Politik Jawa. Jurnal Review Politik, 5(2), 254-278.

Creswell, J. W. (2014). Research Design: Qualitative, Quantitative and Mixed Methods Approaches. Thousand Oaks, CA: Sage Publications Inc.

Fitrahayunitisna, F. (2018). Kontradiksi Kecantikan, Mentalitas, dan Identitas Perempuan dalam Novel Ammba Karya Laksmi Pamuntjak. Hasta Wiyata, 1(1), 1-14. 
Furqon, S., \& Busro, B. (2017). Doktrin Mistisisme Al-Ghazali (Sufisme sebagai Etape Perjalanan Spiritual). Syifa al-Qulub, 2(1), 35-46.

Gunawan, A. (2016). Produksi Naskah dan Mistisisme Aksara dalam Bhīma Svarga. Manuskripta, 6(1), 11-39.

Miswari, M. (2017). Filosofi Komunikasi Spiritualitas: Huruf sebagai Simbol Ontologi dalam Mistisme Ibn 'Arabī. Jurnal Al-Hikmah, 9(14), 12-30.

Mulder, N. (2013). Mistisisme Jawa Ideologi di Indonesia. Yogyakarta: LKiS.

Nisa, A. (2019). Motif dan Eeksistensi Mistisisme dalam Novel Misteri Perawan Kubur, Dendam Iblis Cantik, dan Dosa Turunan Karya Abdullah Harahap. Jurnal Sapala, 5(1), $1-17$.

Pamuntjak, L. (2013). Amba. Jakarta: Anggota IKAPI.

Rudin, T. (2017). Ajaran Taoisme dan Mistisisme Islam (Studi Komparatif). Jurnal Intelektualita: Keislaman, Sosial dan Sains, 6(2), 271-294.

Setiawan, A. (2019). Mistisisme sebagai Bentuk Literasi Budaya di Kalangan Masyarakat Jawa. Paper presented at the SENASBASA (Seminar Nasional Bahasa dan Sastra ), Malang

Setiawan, A., \& Qurani, H. B. (2017). Nilai Karakter Cinta Lingkungan Melalui Karakterisasi Tokoh pada Novel Dari Rahim Ombak Karya Tison Sahabuddin Bungin. KEMBARA: Jurnal Keilmuan Bahasa, Sastra, dan Pengajarannya, 3(2), 123-134.

Wahidi, A. (2013). Mistisisme sebagai Jembatan Menuju Kerukunan Umat Beragama. Ulul Albab: Jurnal Studi Islam, 14(2), 135-146.

Widijanto, T. (2018). Jagad Alus Mistis Jawa dalam Cerpen-Cerpen Danarto dan Fantasi Magis Ternate dalam Novel Cala Ibi Karya Nukila Amal. JENTERA: Jurnal Kajian Sastra, $7(1), 102-126$.

Yuantisya, M., Nurizzati, N., \& Bakhtaruddin. (2018). Representasi Fakta-Fakta Sosial-Politik dalam Novel Amba Karya Laksmi Pamuntjak. Bahasa dan Sastra, 5(2), 60-74.

Yusantia, D., Laila, A., \& Rahmat, W. (2019). Mistik dalam Novel Gentayangan Pilih Sendiri Petualangan Sepatu Merahmu Karya Intan Paramaditha (Tinjauan Sosiologi Sastra). Jurnal Bahasa: Bahasa dan Sastra Indonesia serta Pengajarannya, 1(1), 19-27. 